\section{Inhibitory potential test of oyster mushrooms (pleurotus spp) extract on the growth of streptococcus mutans (in vitro)}

\author{
Fajriani, ${ }^{,}$Eka P. Rati
}

\title{
Abstract
}

Objective: The objective of this study was to determine the inhibitory effect of the oyster mushroom extract (pleurotus spp) on streptococcus mutans bacteria.

Material and Methods: This study was a laboratory-based experimental studies with post test only control group design used kirby bauer agar/diffusion method. This study used extract concentrations of 20\%, 30\%, 50\% and positive control (chlorhexidine) with 4 times repetition of the treatment. The measuring instrument was a caliper with millimeters $(\mathrm{mm})$.
Results: One way anova test showed a significant difference of the oyster mushroom extract against the inhibition zone diameter of streptococcus mutans bacteria formed at concentrations of $20 \%, 30 \%$, $50 \%$ and positive controls with a mean of $11.3 \mathrm{~mm}, 12.6 \mathrm{~mm}, 13.8 \mathrm{~mm}$ and $19.6 \mathrm{~mm}$. Data test results obtained $p=0.000(p<0.05)$. This showed that oyster mushrooms extract in inhibiting the growth of streptococcus mutans bacteria were categorized as strong category. Conclusion: Oyster mushrooms extract (pleurotusspp) has inhibitory effect on streptococcus mutans bacteria.

Keywords: Bacterial inhibitory effect, Oyster mushroom (pleurotusspp) extract, Streptococcus mutans

Cite this Article: Fajriani, Rati EP. 2019. Inhibitory potential test of oyster mushrooms (pleurotusspp) extract on the growth of streptococcus mutans (in vitro). Journal of Dentomaxillofacial Science 4(1): 44-46. D01:10.15562/ jdmfs.v4i1.925

Department of Pediatric Dentistry, Faculty of Dentistry, Hasanuddin University, Makassar, Indonesia

${ }^{*}$ Correspondence to: Fajriani, Department of Pediatric Dentistry, Faculty of Dentistry, Hasanuddin University, Makassar, Indonesia fajrianifkg@gmail.com

Received: 19 February 2019 Revised: 25 February 2019 Accepted: 20 March 2019 Available 0nline 1 April 2019

\section{Introduction}

Dental and oral health is not a priority for some people. But in case teeth and mouth are the entrance of germs and bacteria so that it can interfere with the health of other organs. Dental and oral diseases are the sixth highest community complaint in citizen. ${ }^{1}$

In Indonesia, there is an increase in caries prevalence in children aged 3-5 years. According to the Results of Basic Health Research (RISKESDAS) in 2013, dental and oral health problems that occurred in South Sulawesi were 35.6\% and 28.5\% received medical treatment. Based on age group, caries prevalence of $1-4$ years old children was $10.4 \%$, 5-9 years was $28.95 \%$, and $10-14$ years old was $25.2 \%$. The number of children after 1-4 years who received dental and oral health care and education about dental and oral health was only $2.7 \%$, while children after 5-9 years were only $10.1 \%$. Caries that are usually found in children are early childhood caries. ${ }^{1,2}$

In the human oral cavity there are many microorganisms both normal flora and pathogens. Streptococcus mutans is one of the normal flora in the human oral cavity but can turn into a pathogen if there is an increase in bacterial population. Streptococcus mutans the first time isolated from human teeth which experience caries. The term streptococcus mutans taken by the microbiology revise with gram painting. This bacterial ovalshaped and different with the other species of streptococcus, so it called as streptococcus mutans. ${ }^{3}$
Streptococcus mutans has the ability to metabolize sucrose to acid, which can cause enamel demineralization and lead to the onset of dental caries. The growth of streptococcus mutans must be inhibited to prevent the bacterial become pathogens and cause dental caries by giving an antibacterial material. ${ }^{4}$

Research using natural materials has been widely studied with the aim of producing medicines that can support dental health care programs, especially to prevent and treat dental caries. The return of attention to nature (back to nature) is considered useful because in addition to the past the people have believed that natural ingredients can treat various diseases. The use of natural ingredients as a drug also rarely causes adverse side effects compared to those made from synthetic materials. ${ }^{4}$

Natural ingredients that can be used are oyster mushrooms (pleurotus spp). These mushrooms categorized as foods that can provide health benefits from the nutritional content possessed. Studies from several countries prove that oyster mushrooms have many nutrients that contain bioactive components such as terpenoids, steroids, phenols, alkaloids, lectins and nucleotides isolated and identified from the body of the fungus, mycelium and broth cultures from these fungi have biological effects that are beneficial to health. one of them is as an antimicrobial. Mushrooms are a source of antioxidants such as vitamins A, C, carotene, polyphenols 
and flavonoids. Mushrooms are known to have health benefits, one of which is the pleurotus species (oyster mushroom). This type of fungus is widely cultivated in Indonesia using sawdust as a planting medium. ${ }^{5}$

In dental research, there has never been a study of oyster mushrooms in inhibiting a bacterium in the oral cavity. Based on the background, the authors are interested to conduct a study regarding inhibitory test of oyster mushroom (pleurotus spp) in inhibiting streptococcus mutans bacteria in vitro.

\section{Material and Methods}

This research is a laboratory-based experimental study with post-test only control group design using the Kirby Bauer / diffusion method using disk paper which has contained flavanoid extracts and polyphenols from oyster mushrooms then put into the culture media. Kirby Bauer method was carried out to observe the inhibitory zone diameter of certain extracts and produce a good batchtobatch, resulting in satisfactory growth of the most pathogenic bacterial properties. The test has been repeated four times with a concentration of $20 \%$, $30 \%, 50 \%$. The positive control used chlorhexidine and negative control used sterile aquades.

The research tools used petri dishes, round oases, autoclaves, bunsen, erlenmeyer flasks, suction pipettes, filters, rotary evaporators, filter paper, sterile cotton swabs and stationery. The materials used in this study were oyster mushroom (pleurotusspp), culture of streptococcus mutans bacteria, sterile distilled water, $96 \%$ ethanol, paper disk, transport medium, aluminum foil, cotton, Muller Hinton Agar (MHA), Brain Heart Infusion (BHI) and $0.2 \%$ chlorhexidine solution. Samples in the form of oyster mushrooms (pleurotusspp) were cleaned from the remaining dirt. Oyster mushrooms ware cut into small pieces and dried by aerating. After drying the sample is kept in a closed glass container. The oyster mushroom extract was obtained by maceration. The sample in the closed container soaked with $96 \%$ ethanol solution and left for 5 days. After 5 days, the soaked sample was filtered using filter paper. The results of the filter evaporated using a rotary evaporator, so the thick extract of the oyster mushroom was obtained. The thick extract result was put into a vaporized container until all ethanol solvents evaporated.

Streptococcus mutans bacteria ware implanted on sloping media by scraping using an OSE needle, then implanted on the media to be tilted by scratching. The bacteria that had been scratched on the media were incubated in an incubator at $37^{\circ} \mathrm{C}$ for $1 \times 24$ hours then the bacteria were added to BHIB-B media using a sterile needle until the turbidity was the same as McFarland's standard. Sterile cotton swab dipped in bacterial suspension until wet. Cotton sticks ware squeezed for a few hours of deep reaction, then scratched evenly on MHA media until the surface was closed. The data obtained from this study was the result of the inhibition zone of bacterial growth after being given oyster mushroom extract (pleurotus spp) in various concentrations. Data was evaluated statistically. Furthermore, parametric analysis was done with one-way anova $95 \%(\alpha=0.05)$ and continued with LSD test.

\section{Results}

The inhibition zone of each concentration formed has an increase in the inner diameter to inhibit the growth of streptococcus mutans bacteria that measured in units of $\mathrm{mm}$ (millimeters).

Figure 1 concentrations of $20 \%, 30 \%$, and $50 \%$ repetitions were carried out four times and the mean results were $11.3 \mathrm{~mm}, 12.6 \mathrm{~mm}$, and $13.8 \mathrm{~mm}$. These results have a difference from the average results obtained in positive control $(19.6 \mathrm{~mm})$.

From the results of the one-way ANOVA test, the significant results were 0.00 with consideration of the results $<0.05$ which stated that there were significant differences between the inhibitory effects of the concentration of each treatment.

Table 1 showed that the inhibited zone from every concentration increasing the diameter in inhibited the growth of bacteria streptococcus mutans measure with $\mathrm{mm}$ (milimeter). In $20 \%, 30 \%$, and $50 \%$ concentration retake in 4 times as the result with the mean $11.3 \mathrm{~mm}, 12.6 \mathrm{~mm}$ and $13.8 \mathrm{~mm}$. This result have the difference with the result from the positive control with $19.6 \mathrm{~mm}$. Based on this observation, there is a comparison between the oyster mushroom (pleurotus spp) showed that from 3 extract concentration of oyster mushroom (pleurotus spp) have a different inhibited growth of streptococcus mutans significantly and the effect of antibacterial increasing in concentration solution from $20 \%$, $30 \%$ and $50 \%$ showed there is a positive relation between the produce of inhibited zone and the use of concentration.

\section{Discussion}

This study was a laboratory experiment with the aim to determine the inhibitory effect of oyster mushroom extract (pleurotus spp) on streptococcus mutans bacteria. The results of the result of this study showed that inhibitory zones formed by concentrations of $30 \%, 40 \%$ and $50 \%$ in oyster mushroom extracts (pleurotus spp). According to- 
Table 1 The average yield of inhibition zone diameter and standard deviation.

\begin{tabular}{lcc}
\hline Category & $\begin{array}{c}\text { Inhibited Zone Diameter } \\
\text { Mean } \pm \text { SD }\end{array}$ & Value p \\
\hline Extract 20\% & $11.30 \pm 2.78$ & \\
Extract $30 \%$ & $12.68 \pm 2.38$ & \\
Extract $50 \%$ & $13.81 \pm 2.91$ & 0.014 \\
Control + & $19.60 \pm 8.83$ & \\
Control - & $6.50 \pm 0.00$ & \\
\hline
\end{tabular}

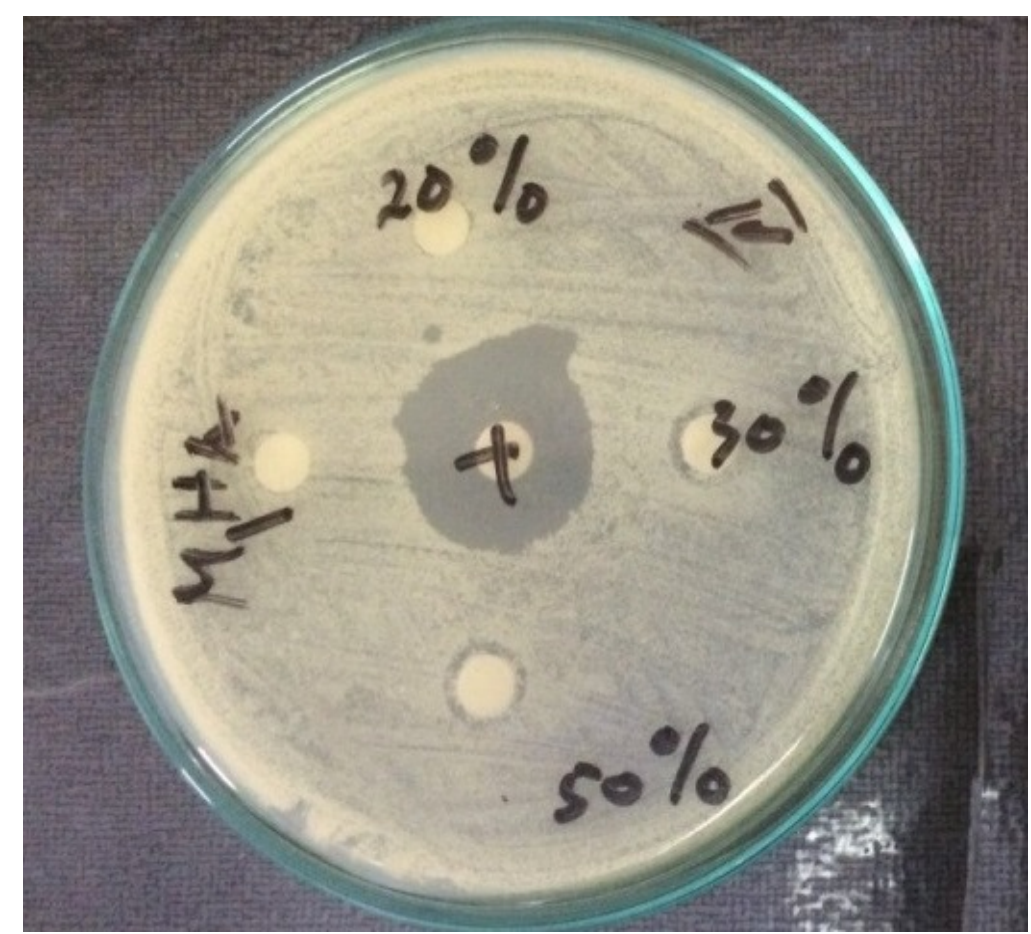

Figure 1 The inhibition zone of oyster mushroom on streptococcus mutans bacteria

Davis and stout statement, the diameter zone inhibited $5 \mathrm{~mm}$ or less than that categorized as weak, the diameter zone inhibited $5-10 \mathrm{~mm}$ categorized as medium, and the diameter zone inhibited 10-20 $\mathrm{mm}$ categorized as strong or more than $20 \mathrm{~mm}$ categorized as the strongest.

Oyster mushroom (pleurotus spp) was made into extract in this study. The positive control that were used in this research is chlorhexidine $0.2 \%$ as the comparison solution between the effect of antimicrobial medicine and extract solution oyster mushroom (pleurotus spp). The study conducted by Saskiawan..$^{5}$ suggested that oyster mushrooms have many nutrients that contain bioactive components such as terpenoids, steroids, phenols, alkaloids, lectins and nucleotides isolated and identified from the fruit's body of mycelium and broth cultures from these from these fungi have biological effects that are beneficial to health. One of them is as an antimicrobial. ${ }^{5}$

Flavanoids in extract can destroy the bacterial wall cell through the difference of the polar between lipid of DNA bacteria and the alcohol group in flavonoid so it makes the wall destroyed and the molecules enter into the nucleus of bacteria. ${ }^{6}$

\section{Conclusion}

Based on this study, it can be concluded that the oyster mushroom extract (pleurotus spp) has an inhibitory effect on the growth of streptococcus mutans bacteria. The concentrations that have a larger inhibitory zone ware concentrationof $50 \%$, $30 \%$, and $20 \%$. So the result of the diameter of the inhibitory zone was greater if the concentration of oyster mushroom (pleurotus spp) was higher.

Further research is needed on the antimicrobial effects of oyster mushrooms (pleurotus spp) on different bacteria and more varied concentrations. It is also necessary to test the inhibitory effect using other methods, mediums and solvents.

\section{Acknowlegment}

The authors would like to thank the Faculty of Dentistry Hasanuddin University for the provided support and all involved in this research.

\section{Conflict of Interest}

The authors report no conflict of interest

\section{References}

1. Riset Kesehatan Dasar (RISKESDAS) 2013. Jakarta: Depkes RI; 2013. p. 110.

2. Situmorang HRR. Uji konsentrasi hambat minimum (Khm) ekstrak daun leilem (clerodendrum minahassae L.) terhadap bakteri streptococcus mutans. J Ilmiah Farmasi 2016;5: 70 .

3. Riwandy A. Aktivitas Anti bakteri ekstrak air kelopak bunga rosella (hibiscus sabdariffa L.) terhadap pertumbuhan streptococcus mutans in VITRO. Dentino 2014;2: 61.

4. Saskiawan I. Pemanfatan ekstrak jamur tiram (pleurotusspp.) pada penyimpanan daging ayam pada suhu ruang $\left(26^{\circ} \mathrm{C}\right)$. J Biolo Indonesia 2017;13: 280.

5. Fatmawati D. Hubungan biofilm streptococcus mutans terhadap resiko terjadinya karies gigi. JKG UNEJ 2011;8.

6. Jannata HR. Daya anti bakteri ekstrak kulit apel manalagi (malus sylvestris Mill.) terhadap pertumbuhan streptococcus mutans. e-Jurnal Pustaka Kesehatan 2014;2:

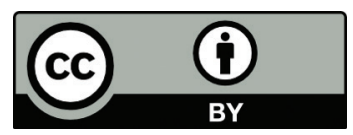

This work is licensed under a Creative Commons Attribution 